Kumawula, Vol. 3, No.1, April 2020, Hal 60 - 72 DOI:http://10.24198/kumawula.v3i1.24732

ISSN 2620-844X (online)

Tersedia online di http://jurnal.unpad.ac.id/kumawula/issue/view

\title{
POTENSI DAN MASALAH 5 ASPEK CITARUM HARUM MELALUI METODE CAUSE IMPACT TREE DI DESA KADAKAJAYA KECAMATAN TANJUNGASARI KABUPATEN SUMEDANG
}

\author{
Desi Yunita \\ Departemen Sosiologi, Fakultas Ilmu Sosial dan Ilmu Politik, Universitas Padjadjaran \\ dey.radsya@gmail.com
}

\begin{abstract}
ABSTRAK
Kegiatan ini ditujukan untuk mengetahui potensi dan masalah dari lima aspek yang menjadi fokus program Citarum harum, yaitu mengenai lahan kritis dan erosi, pengolahan sampah dan limbah agro, pengendalian run off, serta sanitasi lingkungan dan mitigasi bencana. Pada kegiatan ini masyarakat diajak untuk menemukenali potensi dan masalah yang terjadi dilingkungan mereka terkait pada lima aspek tersebut. Metode yang dalam kegiatan ini adalah Cause Impact Tree, dimana sebelumnya juga telah dilakukan penilaian dengan menggunakan beberapa teknik PRA. Dari kegiatan ini beberapa potensi dan masalah terkait dengan lima bidang yang berhasil diidentifikasi diantaranya, lahan kritis dan erosi lebih disebabkan oleh pertanian tanpa terasering dan penggunaan mulsa untuk pertanian hal tersebut dilakukan sebagai strategi intensifikasi lahan agar hasil panen lebih banyak dan lebih untung secara ekonomi; pengendalian run off tidak dilakukan masyarakat karena alasan efektivitas penggunaan lahan; pada pengelolaan sampah dan limbah agro meskipun tidak besar namun masih ada sebagian warga yang membuang sampah di selokan; beberapa potensi bencana yang mungkin terjadi adalah longsor atau tanah bergerak. Penggunaan metode cause impact tree tersebut telah berhasil mendorong masyarakat untuk mengetahui apa yang menjadi penyebab, masalah, dan solusi yang dimungkinkan untuk dilakukan.
\end{abstract}

Kata Kunci: PRA, Cause impact tree, Citarum harum

\begin{abstract}
This activity is intended to determine the potency and problems are the focus of Citarum Harum Programme. In this activity the community is invited to identify the potency and problems that occur in their environment related to five aspects. The method in this activity is the Cause Impact Tree, which previously has also been assessed using several PRA techniques. From this activity several potency and problems related to the five areas identified were, critical land and erosion more caused by agriculture without terracing and the use of mulch for agriculture was done as a strategy of land intensification so that the yields were more profitable; control of run off is not carried out by the community due to reasons for the effectiveness of land use; Even though the waste management and agro waste are not large, there are still some people who throw rubbish in the gutter; Some potential disasters that may occur are landslides or moving land. The use of the cause impact tree method has succeeded in encouraging the public to know what are the causes, problems and possible solutions.
\end{abstract}

Keywords: PRA, Cause impact tree, Citarum Harum 


\section{Pendahuluan}

Sudah banyak dikemukakan mengenai peran dan fungsi sungai citarum yang sangat penting bagi masyarakat khususnya di Provinsi Jawa Barat. Namun, meski diketahui pentingnya fungsi dan peran sungai Citarum tersebut bagi masyarakat, hingga saat sungai Citarum masih terus mengalami tekanan. Riset yang dilakukan BlackSmith Institute (2013:14) misalnya, mengungkapkan bahwa Citarum adalah salah satu sungai dari sepuluh sungai yang paling mengancam kehidupan di Dunia. Laporan tersebut mengungkap bahwa kandungan timbal di sungai Citarum lebih dari 1000 kali standar USEPA dalam air minum. Selain itu, dilaporan tersebut juga terungkap bahwa buletin APN Science 2013 menemukan konsentrasi aluminium, mangan, dan besi di sungai juga secara signifikan lebih tinggi daripada rata-rata dunia (Sarin, Rajiv, 2011:109). EPA (2013) menyebutkan bahwa Mangan dalam air minum, misalnya, memiliki standar 50 ppb untuk meminimalkan efek kesehatan yang merugikan. Sedangkan Air di DAS Citarum memiliki konsentrasi mangan yang hampir empat kali lipat dari level yang direkomendasikan. Selain dari tekanan pencemaran pada kandungan mineral airnya, sungai citarum juga tercemar oleh sampah yang sangat besar. Setidaknya, setiap hari sungai Citarum harus menampung 1.500 ton sampah baik itu sampah rumah tangga maupun sampah yang dihasilkan oleh industri.

Informasi faktual mengenai kandungan logam berat dan sampah di sungai Citarum yang digambarkan itu menjadi bukti bahwa tekanan terhadap sungai Citarum nyata terjadi. Oleh karenanya Pemerintah Pusat merasa perlu untuk mengambil alih upaya revitalisasi sungai citarum ini. Beberapa program sudah beberapa kali dicanangkan namun beberapa program tersebut tidak dapat mencapai target yang diinginkan. Awal tahun 2018 program baru digulirkan oleh pemerintah dengan nama program "Kembalikan Citarum Harum". Program prestisius ini diharapkan dapat kembali merevitalisasi sungai Citarum sejak dari bagian hulu nya.

Akan tetapi, walaupun program revitalisasi sudah dicanangkan, namun langkah yang ditempuh tidaklah mudah. Kompleksnya permasalahan yang dihadapi di lapangan, kerusakan lingkungan yang makin parah, kesadaran yang rendah dari masyarakat yang tinggal di wilayah sungai, dan beberapa persoalan lainnya menjadi bukti bahwa revitalisasi Citarum yang di programkan oleh pemerintah tersebut tidak mudah. Beberapa permasalahan yang terjadi di hulu sungai Citarum juga penting diketahui, sehingga selain dapat mengetahui bentuk-bentuk potensi yang dapat mengancam sungai Citarum, juga dapat menjadi dasar dalam penyusunan program yang mendukung upaya revitalisasi Citarum tersebut. 
Sebagai bentuk dukungan terhadap program pemerintah tersebut, Universitas Padjadjaran telah melakukan serangkaian pengkajian khususnya di wilayah yang termasuk dalam sub DAS Citarik. Kajian tersebut dilakukan untuk menyediakan informasi dan data terkait permasalahan yang ada di wilayah sub DAS Citarik, khususnya pada 5 aspek yaitu lahan kritis dan erosi, konservasi air dan pengendalian run off, sampah dan limbah agro, sanitasi lingkungan, dan mitigasi bencana.

\section{Metode}

Kegiatan ini dilakukan dengan mengkombinasikan beberapa metode partisipatif seperti pemetaan sosial dan canvas dengan penekanan pada analisis Cause Impact Tree. Penggunaan metode Cause Impact Tree ini diyakini dapat lebih menggali suatu masalah dari sebab, akibat yang timbul, hingga faktor mendasar yang menjadi penyebab terjadinya masalah pada 5 aspek kajian yang menjadi focus program citarum harum.

Selain itu, analisis cause impact tree ini juga membantu para pihak yang berkepentingan di desa dalam membangun gambaran realistis dan kesadaran akan masalah dengan mengidentifikasi penyebab mendasar dan dampaknya yang paling penting. Selanjutnya, dalam konteks program citarum harum, diketahuinya permasalahan ini juga penting untuk menentukan program apa yang menjadi prioritas untuk diatasi terlebih dahulu. Terdapat enam tahapan cara mengembangkan analisis dari metode cause impact tree., yaitu; identifikasi masalah yang ada di dalam area persoalan, menetapkan apa masalah inti, merumuskan penyebab masalah inti, merumuskan dampak masalah inti, menggambarkan diagram yang mewakili sebab dan akibat masalah, serta mereview dan verifikasi menyeluruh.

Selanjutnya, dalam mengetahui beberapa masalah yang berkaitan dengan 5 aspek yang menjadi focus kajian ini, digunakan juga beberapa teknik partisipasi, seperti peta sketsa, transek, kalender musim, diagram venn dan canvas, untuk mengumpulkan informasi mengenai gambaran merangkaikan fakta dan menampilkannya dalam bentuk kronologi kejadian dan perubahan lingkungan dan keadaan biofisik dan biososial, terutama terkait 5 aspek kajian yang menjadi perhatian program Citarum Harum yakni lahan kritis dan erosi, konservasi air dan pengendalian Run Off, pengelolaan sampah dan limbah pertanian, sanitasi dan mitigasi bencana.

\section{Hasil dan Pembahasan}

Desa kadakajaya merupakan salah satu wilayah sub das Citarik, yang menjadi bagian dari Sungai Citarum. Desa ini terletak diketinggian 1250 mdpl, dengan luas wilayah 342.63 
$\mathrm{Ha}^{2}$. Mayoritas warga masyarakat berprofesi sebagai petani dan buruh tani dengan komoditi tanaman padi dan hortikultura (sayur mayur), seperti cabe, tomat, kubis, wortel, dan sebagainya. Tanaman padi mayoritas ditanam di bagian utara desa, karena lokasinya yang berdekatan dengan aliran sungai dengan lahan yang cenderung datar, sedangkan tanaman sayuran dan hortikultura ditanaman di sebelah barat desa yang berbatasan langsung dengan wilayah hutan perhutani. Komposisi jumlah masyarakat yang bertani padi jumlahnya lebih banyak jika dibandingkan masyarakat yang membudidayakan tanaman hortikultura hal itu terjadi karena luasan lahan yang sedikit, juga karena yang membudidayakan tanaman sayuran jumlahnya lebih sedikit hanya sebesar 7,16 hektar, sedangkan lahan persawahan yang dimiliki warga adalah 165, 6 hektar. Selain dari pertanian, masyarakat juga umumnya membudidayakan ternak seperti domba, kambing, dan sapi, sebagai salah satu strategi ekonomi karena suatu waktu bisa dijual jika diperlukan. Selanjutnya jika dilihat dari sisi demografi diketahui bahwa jumlah penduduk Desa Kadakajaya berjumlah 4572 jiwa dengan komposisi 2346 jiwa laki-laki dan 2226 jiwa perempuan.

\section{Uraian Kondisi mengenai permasalahan pada 5 Aspek Kajian}

Untuk mengetahui potensi dan masalah yang ada di Desa Kadakajaya terkait dengan 5 aspek yang menjadi fokus program Citarum Harum ini dilakukan penilaian melalui observasi untuk mengetahui gambaran mengenai potensi dan masalah yang terdapat di Desa Kadakajaya tersebut. Observasi ini diperlukan untuk mendapatkan informasi berdasarkan sudut pandang peneliti yang selanjutnya akan diuraikan dan disimulasikan bersama masyarakat dalam kegiatan kelompok diskusi terfokus bersama masyarakat desa. Beberapa temuan pada proses observasi terkait lima aspek kajian program citarum harum diantaranya adalah:

\section{Lahan kritis dan Erosi}

Berdasarkan observasi yang dilakukan, diketahui bahwa meskipun memiliki potensi potensi lahan kritis, namun jumlah nya sangat sedikit yaitu pada lahan pertanian sayuran (hortikultura). Lahan-lahan tersebut dimasukkan dalam kategori lahan kritis berdasarkan definisi yang dikemukakan oleh Wirosoedarmo dkk (2007) yaitu lahan yang saat ini tidak produktif karena pengelolaan dan penggunaan tanah yang tidak atau kurang memperhatikan syarat-syarat konservasi tanah dan air sehingga menimbulkan erosi, kerusakan-kerusakan kimia, fisik, tata air dan lingkungannya. Selain itu, penetapan lahan kritis juga mengacu pada definisi lahan kritis yang ditetapkan sebagai lahan yang telah mengalami kerusakan secara fisik sehingga kehilangan atau berkurang fungsinya sampai pada batas toleransi yang telah 
ditentukan sesuai dengan peraturan menteri kehutanan (P.32/Menhut-II/2009). Merujuk pada definisi lahan kritis tersebut, maka lahan pertanian sayuran yang ada di desa Kadakajaya masuk dalam kateogri kritis. Karena metode pengolahan lahan, penggunaan pupuk, dan jenis komoditi yang dibudidayakan oleh masyarakat akan mengarahkan lahan secara jangka panjang untuk menjadi kritis. Beberapa indikasi mengenai hal tersebut diantaranya terlihat dari semua lahan yang dibudidayakan menggunakan mulsa. Penggunaan mulsa ini tidak memungkinkan lahan untuk diteraseringkan, penggunaan mulsa mendorong air untuk langsung mengalir tanpa penahan yang menyebabkan lahan tererosi, selain itu tingginya penggunaan pupuk kimia yang dibarengi dengan penggunaan mulsa, menyebabkan kandungan kimia dari pupuk tersebut langsung mengalir ke sungai. Penggunaan mulsa ini dilakukan oleh masyarakat sebagai upaya meningkatkan produksi pertanian, dengan produksi yang meningkat diharapkan penghasilan masyarakat juga akan meningkat. Penggunaan mulsa juga telah mendorong masyarakat menebang pohon-pohon yang menjadi penahan tanah yang akan mengurangi resiko terjadinya erosi.

\section{Konservasi air dan pengendalian Run off}

Observasi yang dilakukan memperlihatkan bahwa masyarakat belum melakukan upaya konservasi air dan pengendalian run off. Pada konteks air untuk memenuhi kebutuhan rumah tangga, sejauh ini masyarakat sangat bergantung pada sumber air yang ada di wilayah hutan. Pengamatan yang dilakukan pada musim kemarau menunjukkan bahwa hampir tidak ada persediaan air yang dapat dimanfaatkan oleh masyarakat. bentuk konservasi seperti menambung air yang dilakukan pada musim-musim dengan air melimpah dan akan dimanfaatkan pada saat musim kemarau juga belum dilakukan oleh masyarakat. sehingga pada musim kemarau kebanyakan lahan pertanian hortikultura efektif tidak bisa diolah. Disisi lain, ketergantungan masyarakat petani hortikultura pada penggunaan mulsa justru memperlihatkan bahwa upaya pengendalian Run Off tidak dilakukan oleh masyarakat.

\section{Pengelolaan Sampah dan limbah agro}

Observasi berkaitan dengan pengelolaan sampah dan limbah agro, yang dilakukan oleh masyarakat untuk mengatasi masalah sampah diantaranya dengan mendirikan bank sampah, atau secara mandiri memusnahkan sampah tersebut. Namun, meskipun sudah ada bank sampah, masih saja ada masyarakat yang membuang sampah secara langsung ke saluran air/selokan, pekarangan, atau dilahan kosong. Belum adanya aturan mengenai larangan membuang sampah secara langsung ke selokan tersebut membuat masyarakat tetap merasa bebas membuang sampah, selain dari tingkat kesadaran yang masih rendah dari masyarakat. 
Obervasi berkaitan dengan permasalahan limbah agro juga menunjukkan belum ada upaya untuk mengatasi limbah agro, terutama limbah yang dihasilkan dari pupuk kimia yang dipergunakan. Sedangkan untuk limbah agro pasca panen, meskipun belum semua petani melakukan, akan tetapi sudah ada upaya dari beberapa petani yang memanfaatkan limbah agro untuk dijadikan kompos sehingga dapat dimanfaatkan sebagai pupuk pertanian pada musim tanam selanjutnya.

\section{Sanitasi Lingkungan}

Hasil observasi memperlihatkan bahwa upaya sanitasi lingkungan juga belum dilakukan oleh masyarakat. meskipun sampai saat observasi dilakukan sanitasi lingkungan belum menjadi masalah, namun beberapa aspek dilapangan memperlihatkan bahwa kedepannya sanitasi lingkungan juga akan mengalami kendala di masyarakat Desa Kadakajaya.

Beberapa indikasi yang terlihat dapat menjadi masalah terkait sanitasi lingkungan diantaranya, letak kandang ternak yang berdampingan dengan rumah, saluran pembuangan rumah tangga yang tidak tertata dengan baik, kebiasaan masyarakat yang cenderung membuang sampah di selokan pembuangan juga dapat menjadi masalah pada aspek sanitasi lingkungan ini.

\section{Mitigasi Bencana}

Hasil observasi dan wawancara memperlihatkan bahwa masyarakat telah berhasil mengidentifikasi potensi-potensi bencana yang mungkin terjadi di desa mereka. Namun sejauh ini belum ada upaya untuk mengatasi potensi bencana tersebut. beberapa potensi bencana yang mungkin terjadi di desa Kadakajaya adalah longsor, erosi, tanah bergerak.

\section{Diskusi Kelompok Terfokus Menggunakan metode Cause Impact Tree}

Temuan Observasi lapangan ini selanjutnya, dikomparasikan bersama-sama dengan beberapa tokoh masyarakat terpilih, yaitu tokoh-tokoh masyarakat yang mengetahui tentang persoalan-persoalan yang ada di masyarakat khususnya yang berkaitan dengan lima aspek kajian program Citarum Harum. Pada fokus mengenai lahan kritis dan erosi; potensi masalah terkait dengan aspek ini dipengaruhi penggunaan mulsa yang masih tinggi, penggunaan mulsa mendorong penggunaan pupuk kimia yang tinggi pula, penggunaan mulsa tersebut dilakukan untuk mendapatkan hasil panen sebanyak-banyaknya yang akan berpengaruh pada pendapatan petani. Penggunaan mulsa yang tinggi juga menyebabkan semua pohon yang menjadi penahan lahan ditebang. Hal itulah yang menyebabkan konservasi air dan pengendalian run 
off tidak berjalan maksimal. Selain itu, masyarakat juga sangat tergantung kebutuhan airnya dari wilayah hutan. Beberapa potensi masalah yang memiliki korelasi dengan konservasi air dan pengendalian run off seperti penggunaan pupuk kimia yang sangat tinggi, bank sampah yang tidak berjalan dengan maksimal, karena tidak ada lembaga yang secara khusus bertugas mengelola, disamping kesadaran pengelolaan sampah di masyarakat juga masih sangat rendah. Konservasi air dan pengendalian run off sangat terkait juga dengan ketersediaan pohon, tidak adanya pohon dilahan menunjukkan bahwa tidak ada upaya konservasi air dan pengendalian run off. Pada aspek pengelolaan pengelolaan sampah dan limbah agro, masalah utama yang dihadapi oleh masyarakat adalah tidak berjalannya bank sampah karena tidak ada pengelola yang khusus terkait dengan bank sampah, disamping tingkat kesadaran masyarakat dalam pengelolaan sampah yang masih rendah. Hal itu berdampak pada banyaknya sampah yang dibuang dibelakang kantor desa, atau dibuang disaluran air. Akibatnya, meskipun tidak besar namun masyarakat dari hulu juga berkontribusi menimbulkan beban berlebih pada sungai citarum baik itu dari sampah yang terbawa arus sungai, atau dari material kandungan bahan kimia yang tergerus dan terbawa arus. Berkaitan dengan sanitasi lingkungan, diketahui bahwa sanitasi lingkungan yang tidak tertata dengan baik ini disebabkan oleh tingginya tingkat pencurian ternak, sehingga masyarakat lebih condong memelihara ternak dipekarangan rumah, hal inilah yang berpeluang memberikan beban lingkungan. Pada mitigasi bencana, diketahui bahwa beberapa titik lokasi di desa memiliki potensi longsong dan tanah bergerak, hal tersebut terkorelasi dengan kurangnya pohon yang menjadi penahan tanah karena ditebang untuk kebutuhan lahan pertanian. Untuk melihat gambaran korelasi lima aspek dan masalah-masalah yang saling mempengaruhinya dapat dilihat pada diagram di bawah ini:

\section{Diagram alur masalah 5 aspek kajian Desa Kadakajaya}




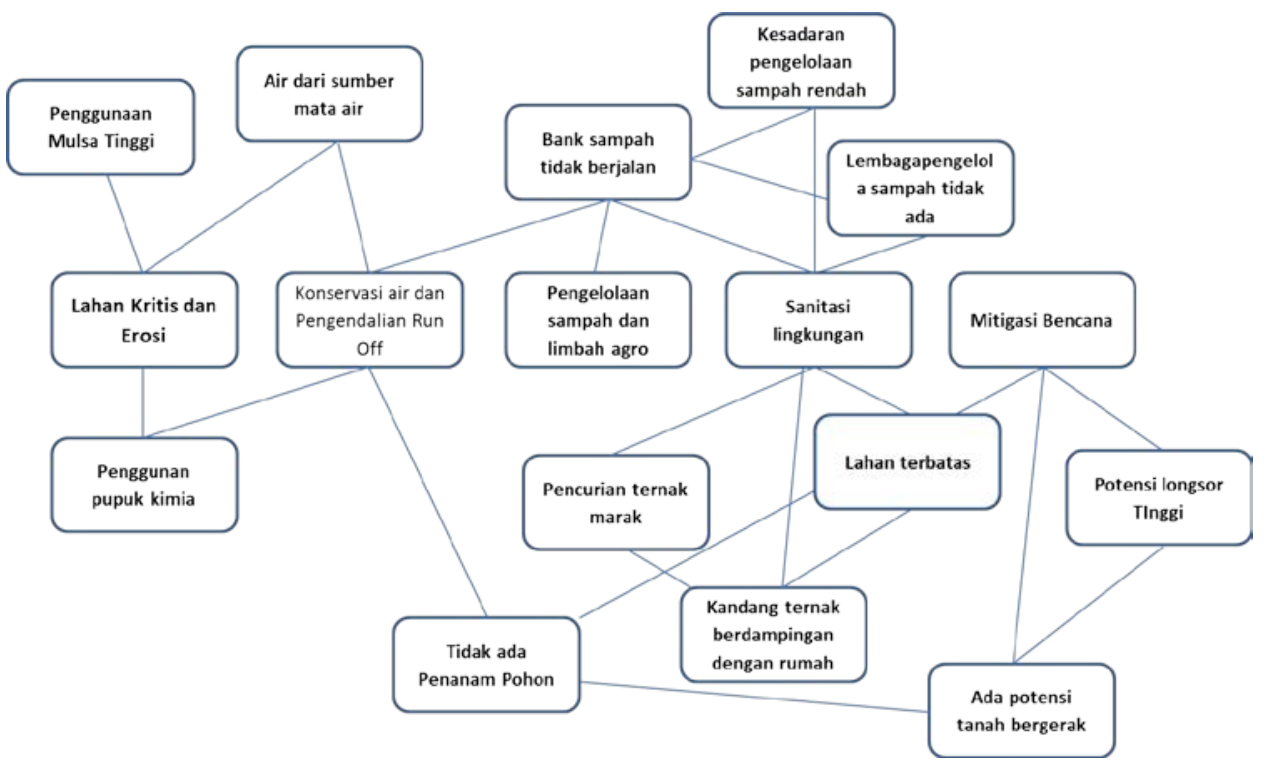

Selanjutnya, untuk menggambarkan semakin jelas, mengenai potensi dan masalah yang ada dilakukan analisa di masing-masing dusun, untuk lebih jelasnya dapat dilihat pada table berikut ini.

Komparasi masalah pada 5 Aspek yang dikaji dalam program Citarum Harum di Desa Kadakajaya

\begin{tabular}{|c|c|c|c|c|}
\hline Aspek Kajian & Dusun 1 & Dusun 2 & Dusun 3 & Dusun 4 \\
\hline $\begin{array}{l}\text { Lahan kritis } \\
\text { dan erosi }\end{array}$ & 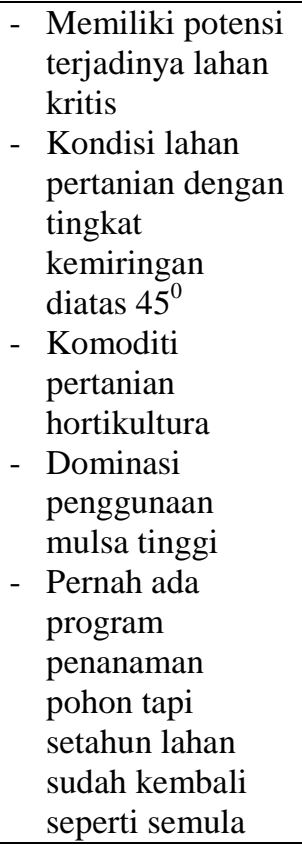 & 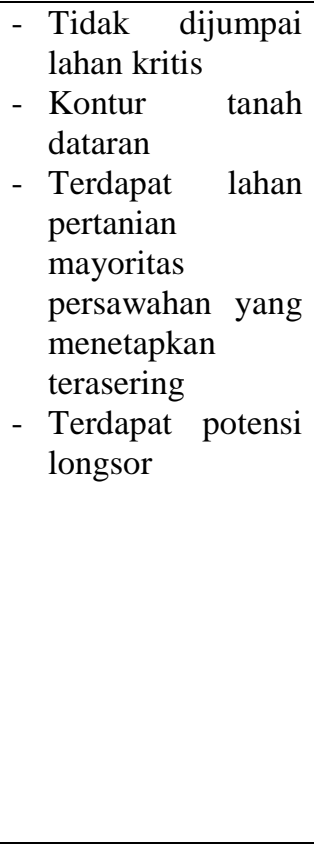 & $\begin{array}{lr}\text { - } & \text { Memiliki potensi } \\
\text { terjadi lahan kritis } \\
\text { karena tidak } \\
\text { adanya pohon } \\
\text { yang menjadi } \\
\text { penahan erosi. } \\
\text { - } & \text { Penggunaan } \\
& \text { pupuk kimia } \\
\text { tinggi } & \end{array}$ & 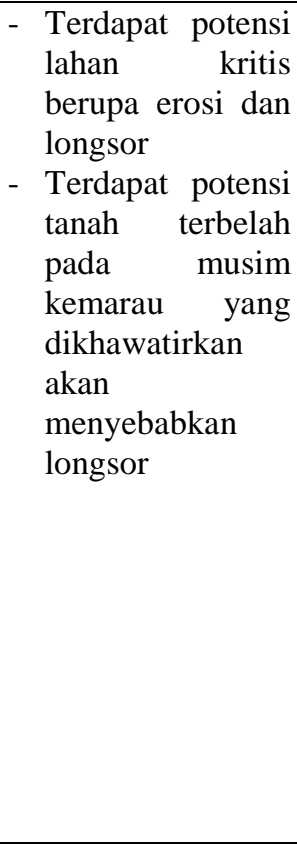 \\
\hline $\begin{array}{l}\text { Konservasi } \\
\text { Air dan } \\
\text { Pengendalian } \\
\text { Run off }\end{array}$ & $\begin{array}{l}\text { - } \text { Tidak ada upaya } \\
\text { konservasi air } \\
\text { - } \\
\text { Sedikit sekali } \\
\text { dijumpai } \\
\text { tanaman tahunan } \\
\text { berupa pohon } \\
\text { yang dapat } \\
\text { menampung air } \\
\text { dan menahan laju }\end{array}$ & $\begin{array}{l}\text { - Belum ada upaya } \\
\text { konservasi air, } \\
\text { baik itu } \\
\text { menabung air } \\
\text { atau upaya } \\
\text { penanaman } \\
\text { pohon. } \\
\text { - } \text { Pasokan air } \\
\text { kedusun } 2 \text { sangat }\end{array}$ & $\begin{array}{l}\text { - } \text { Belum ada upaya } \\
\text { konservasi air } \\
\text { dengan cara } \\
\text { menabung air atau } \\
\text { menanam pohon } \\
\text { - } \text { Musim kemarau } \\
\text { yang panjang } \\
\text { menyebabkan } \\
\text { debit air dari } \\
\end{array}$ & $\begin{array}{l}\text { - } \text { Air masih } \\
\text { didapat dari } \\
\text { sumber - sumber } \\
\text { mata air di dekat } \\
\text { areal persawahan } \\
\text { meskipun kecil } \\
\text { tetapi masyarakat } \\
\text { masih bisa } \\
\text { memanfaatkan } \\
\end{array}$ \\
\hline
\end{tabular}




\begin{tabular}{|c|c|c|c|c|}
\hline & $\begin{array}{ll} & \text { erosi } \\
\text { - } & \text { Dominasi } \\
\text { pertanian } \\
\text { menggunakan } \\
\text { mulsa tinggi } \\
\text { - } & \text { Menjadikan Pola } \\
\text { pertanian } \\
\text { masyarakat } \\
\text { bergantung } \\
\text { musim } \\
\text { - Tidak ada upaya } \\
\text { menabung air } \\
\text { dimusim hujan } \\
\text { - Selokan jadi } \\
\text { tempat } \\
\text { pembuangan } \\
\text { sampah yang } \\
\text { menyebabkan } \\
\text { sumbatan } \\
\end{array}$ & $\begin{array}{l}\text { kurang karena } \\
\text { kemarau. } \\
\text { - } \text { Masyarakat } \\
\text { sepenuhnya } \\
\text { mengandalkan } \\
\text { sumber air }\end{array}$ & $\begin{array}{l}\text { sumber mengecil } \\
\text { atau kering }\end{array}$ & 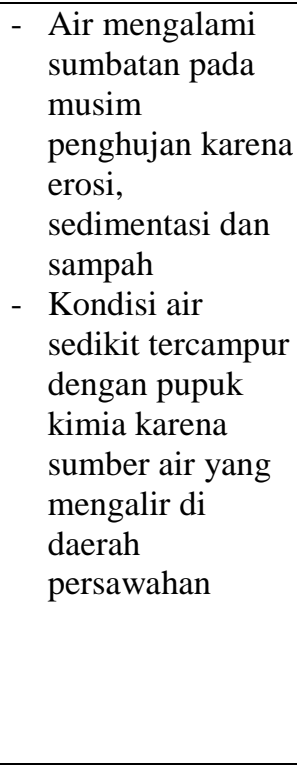 \\
\hline Aspek Kajian & Dusun 1 & Dusun 2 & Dusun 3 & Dusun 4 \\
\hline $\begin{array}{l}\text { Pengolahan } \\
\text { sampah dan } \\
\text { limbah Agro }\end{array}$ & 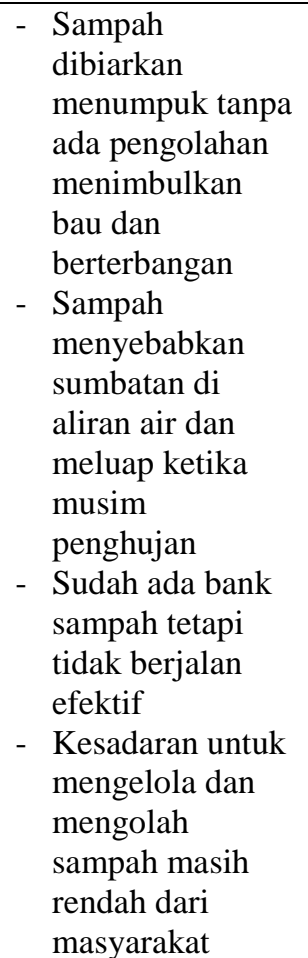 & $\begin{array}{l}\text { - Dusun } 2 \\
\text { merupakan salah } \\
\text { satu dusun yang } \\
\text { paling peduli } \\
\text { dalam menjaga } \\
\text { kebersihan, } \\
\text { terutama RW } 4 . \\
\text { Di RW } 4 \text { tersebut } \\
\text { sudah terdapat } \\
\text { bank sampah } \\
\text { yang berjalan } \\
\text { sudah sistematis } \\
\text { dibandingkan RW } \\
\text { lainnya yang } \\
\text { berada di Desa } \\
\text { Kadakajaya. RW } \\
4 \text { tersebut mejadi } \\
\text { RW yang paling } \\
\text { bersih dan } \\
\text { menjadi } \\
\text { pandangan untuk } \\
\text { RW-RW lainnya. }\end{array}$ & $\begin{array}{l}\text { - } \text { Terdapat bank } \\
\text { sampah yang } \\
\text { mudah diakses } \\
\text { tetapi bank } \\
\text { sampah tidak } \\
\text { berjalan efektif } \\
\text { karena bergantung } \\
\text { dari pengelola dan } \\
\text { karang taruna } \\
\text { - Masyarakat lebih } \\
\text { cenderung } \\
\text { membakar } \\
\text { sampah yang } \\
\text { dihasilkan rumah } \\
\text { tangga }\end{array}$ & $\begin{array}{ll}\text { - } & \text { Tidak terdapat } \\
\text { bank sampah } \\
\text { - } \text { Kesadaran } \\
\text { masyarakat } \\
\text { relative baik } \\
\text { sehingga } \\
\text { pencemaran } \\
\text { sampah lebih } \\
\text { terkontrol } \\
\text { - Ada upaya } \\
\text { pemanfaatan } \\
\text { sampah agro } \\
\text { yang dihasilkan } \\
\text { dari proses panen } \\
\text { menjadi kompos } \\
\text { untuk pupuk } \\
\text { pertanian } \\
\text { meskipun } \\
\text { penggunaan } \\
\text { pupuk kimia juga } \\
\text { masih tinggi }\end{array}$ \\
\hline $\begin{array}{l}\text { Sanitasi } \\
\text { Lingkungan }\end{array}$ & 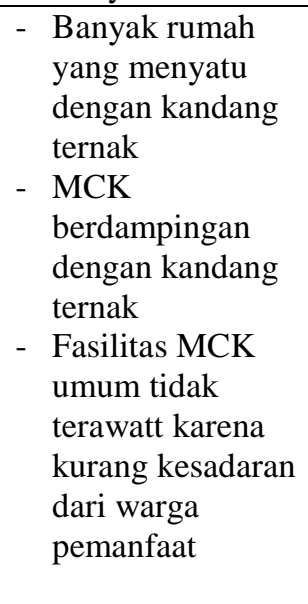 & $\begin{array}{ll}\text { - } & \text { Rumah warga } \\
\text { menyatu dengan } \\
\text { kandang ternak } \\
\text { - } \text { Warga memiliki } \\
\text { lahan rumah } \\
\text { terbatas } \\
\text { - } \text { Kotoran ternak } \\
\text { sudah diolah } \\
\text { menjadi pupuk } \\
\text { - Kandang ternak } \\
\text { tidak memiliki } \\
\text { saluran limbah } \\
\text { cair sehingga } \\
\text { langsung terserap } \\
\text { oleh tanah }\end{array}$ & 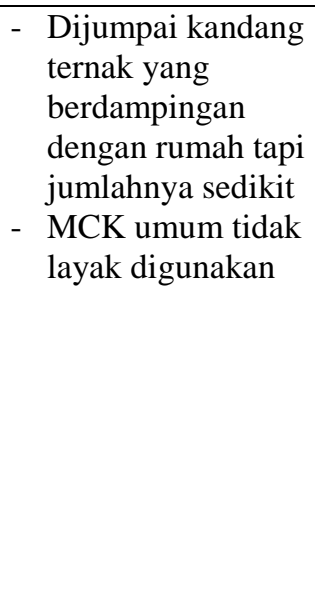 & $\begin{array}{l}\text { - Ada kegiatan } \\
\text { jumat bersih, } \\
\text { seluruh warga } \\
\text { terlibat gotong } \\
\text { royong } \\
\text { - } \text { Masyarakat lebih } \\
\text { banyak } \\
\text { menggunakan } \\
\text { MCK pribadi } \\
\text { yang dibangun } \\
\text { dari bantuan } \\
\text { Koramil } \\
\text { - Kondisi MCK } \\
\text { umum juga } \\
\text { berfungsi baik }\end{array}$ \\
\hline
\end{tabular}




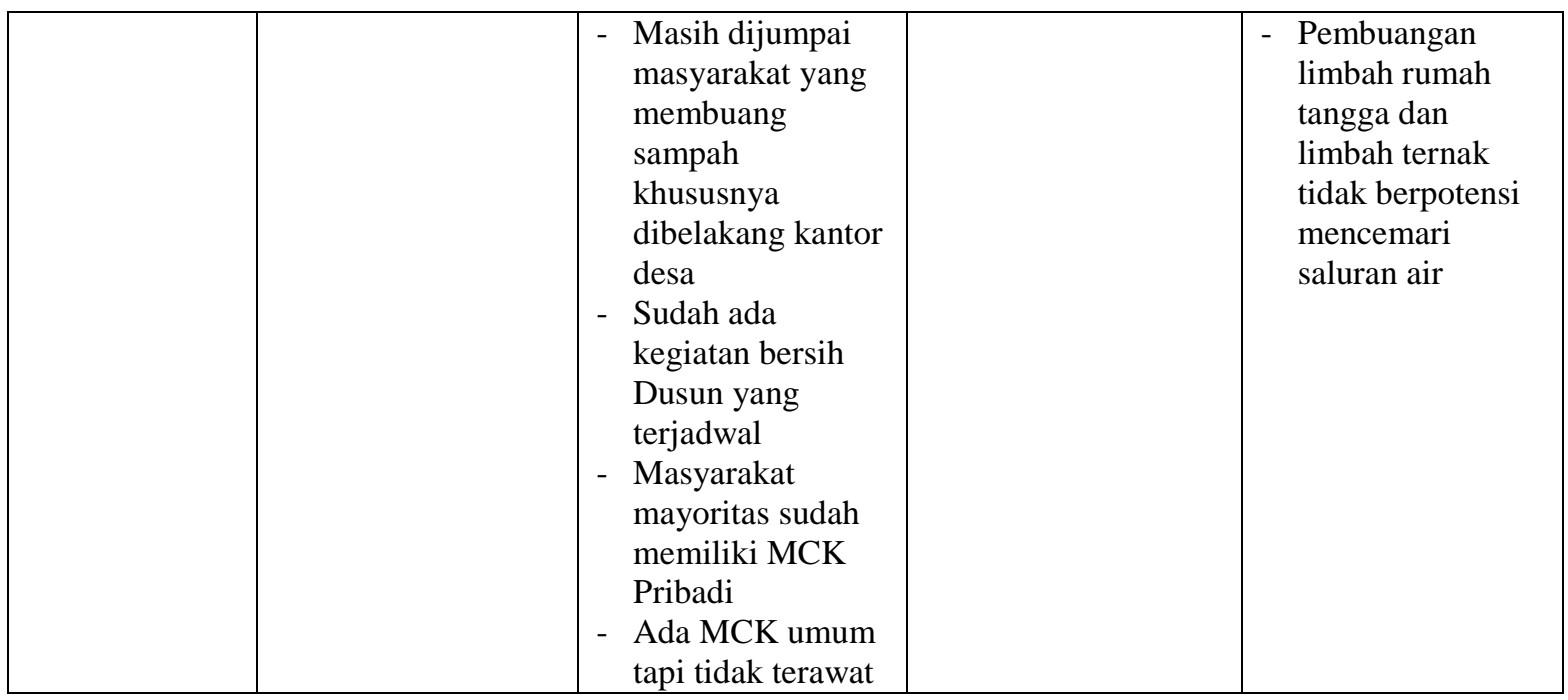

\begin{tabular}{|c|c|c|c|c|}
\hline $\begin{array}{l}\text { Aspek } \\
\text { Kajian } \\
\end{array}$ & Dusun 1 & Dusun 2 & Dusun 3 & Dusun 4 \\
\hline $\begin{array}{l}\text { Mitigasi } \\
\text { Bencana }\end{array}$ & $\begin{array}{l}\text { - Ada potensi } \\
\text { terjadinya longsor } \\
\text { - Sudah ada } \\
\text { sosialisasi bencana } \\
\text { dan kegiatan } \\
\text { simulasi } \\
\text { penanggulangan } \\
\text { bencana yang } \\
\text { diadakan Aparat } \\
\text { Desa dan } \\
\text { KORAMIL. } \\
\text { - Lembaga yang } \\
\text { khusus menangani } \\
\text { bencana sudah } \\
\text { lama tidak aktif, } \\
\text { dibutuhkan } \\
\text { revitalisasi dan } \\
\text { penguatan } \\
\text { Lembaga desa } \\
\text { siaga }\end{array}$ & $\begin{array}{ll}\text { - } & \text { Termasuk daerah } \\
\text { tidak rawan } & \text { bencana alam } \\
\text { - } & \text { Pernah terjadi } \\
\text { kebakaran rumah } \\
\text { - } & \text { Telah dilakukan } \\
\text { sosialisasi } \\
\text { menanggulangi } \\
\text { bencana oleh } \\
\text { pemerintah desa } \\
\text { dan koramil } \\
\text { - } \text { Terdapat sebuah } \\
\text { organisasi atau } \\
\text { lembaga yang } \\
\text { bernama “Desa } \\
\text { Siaga” tetapi sudah } \\
\text { lama tidak aktif. }\end{array}$ & 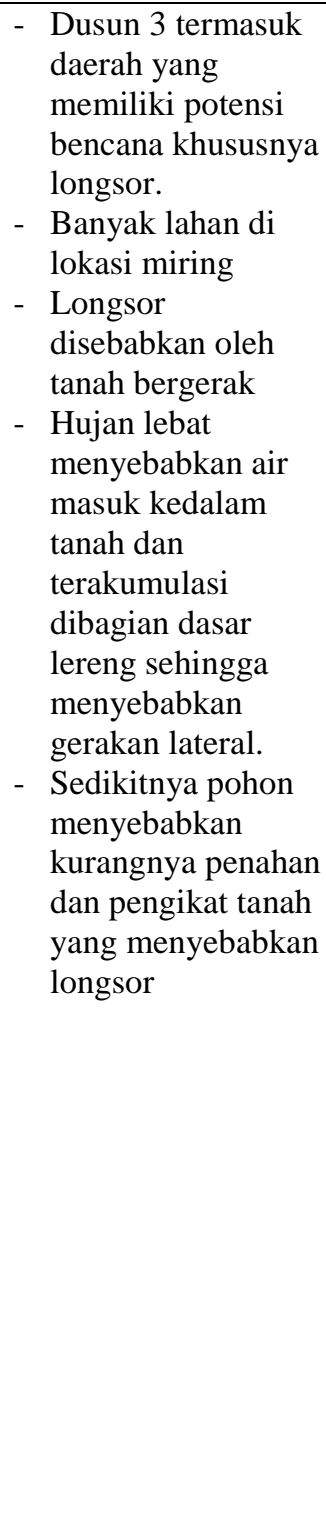 & $\begin{array}{l}\text { - Ditemukan } \\
\text { beberapa kawasan } \\
\text { yang memiliki } \\
\text { potensi longsor } \\
\text { yang besar. } \\
\text { - Beberapa lokasi } \\
\text { pernah longsor } \\
\text { yang serius } \\
\text { sehingga } \\
\text { menyebabkan } \\
\text { kerugian materil } \\
\text { dan non-materil. } \\
\text { - Beberapa faktor } \\
\text { penyebab } \\
\text { diantaranya } \\
\text { pengaruh } \\
\text { cuaca/kemarau } \\
\text { yang } \\
\text { menyebabkan } \\
\text { kadar air dalam } \\
\text { tanah berkurang, } \\
\text { sehingga } \\
\text { menimbulkan } \\
\text { keretakan pada } \\
\text { permukaan tanah } \\
\text { terutama pada } \\
\text { musim kemarau. } \\
\text { - Longsor sering } \\
\text { terjadi ketika } \\
\text { musim hujan } \\
\text { datang. } \\
\text { Masyarakat di } \\
\text { dusun ini tidak } \\
\text { memperhatikan } \\
\text { pengendalian } \\
\text { terhadap lereng } \\
\text { yang curam } \\
\text { seperti }\end{array}$ \\
\hline
\end{tabular}




\begin{tabular}{|l|l|l|l|l|}
\hline & & & & $\begin{array}{l}\text { merevitalisati } \\
\text { terasering, } \\
\text { penanaman } \\
\text { pohon, dsb }\end{array}$ \\
\hline
\end{tabular}




\section{Kesimpulan}

Analisa permasalahan 5 aspek program Citarum Harum di Desa Kadakajaya menggunakan analisa Cause Impact Tree memperlihatkan bahwa, secara keseluruhan berubahnya pola tanam masyarakat dari system terasering (sengkedan) ke penggunaan mulsa, berpengaruh setidaknya pada empat aspek yaitu lahan kritis dan erosi, konsevasi air dan pengendalian run off, serta pengolahan sampah dan limbah agro, dan mitigasi bencana. Sedangkan pada aspek sanitasi lingkungan, tingginya pencurian ternak menjadi masalah utama pada aspek sanitasi lingkungan.

Berdasarkan pada analisa potensi dan masalah menggunakan metode cause impact tree yang berhasil diidentifikasi, untuk memperbaiki kondisi pada lima aspek program citarum harum pemerintah harus membuat terobosan yaitu dengan merubah pola atau system pertanian masyarakat menjadi system pertanian organik, pemerintah juga harus menyediakan market untuk hasil pertanian organic masyarakat sehingga system pertanian organic itu terbudaya di masyarakat. tidak digunakannya mulsa secara langsung dapat memperbaiki empat aspek program citarum harum tersebut. Aspek sanitasi lingkungan juga secara tidak langsung akan terpengaruh, meningkatnya kesejahteraan masyarakat petani dapat mendorong peralihan budaya beternak menjadi hanya bertani saja, karena ternak sejatinya merupakan suplemen ekonomi yang bisa diuangkan sewaktu-waktu jika hasil panen pertanian tidak terlalu bagus. Dengan begitu, perubahan tersebut dapat memperbaiki seluruh aspek yang ada di masyarakat

\section{UCAPAN TERIMA KASIH}

Terima kasih yang sebesarnya penulis ucapkan kepada Universitas Padjadjaran yang telah mendanai terlaksananya kegiatan pengabdian ini melalui skema pendanaan Hibah Internal Unpad pengabdian kepada masyarakat terintegrasi kuliah kerja nyata mahasiswa tahun 2019. Terima kasih yang sebesarnya juga penulis ucapkan kepada seluruh tokoh masyarakat yang terlibat dalam kegiatan ini.

\section{DAFTAR PUSTAKA}

Chambers, Robert.1992.Rural appraisal : rapid, relaxed and participatory.IDS Discussion Paper 311

.tt.Participatory Rural Appraisal Gambaran Teknik-Teknik Berbuat Bersama Berperan Setara Pengkajian dan Perencanaan Program Bersama masyarakat.bandung:Studio Driya Media 
Arsyad, Sitanala. 2000. Konservasi Tanah dan Air. Bandung: Penerbit IPB (IPB Press)

Poernomosidhi , 2005. Banjir Beberapa Penyebab dan Metode Pengendaliannya dalam Perspektif Lingkungan. Yogyakarta : Pustaka Pelajar. 